\title{
Berpikir Komputasi Dalam Pembelajaran Matematika
}

\author{
Rima Aksen Cahdriyana ${ }^{1}$ dan Rino Richardo ${ }^{2}$ \\ 1Program Studi Pendidikan Matematika, Universitas Ahmad Dahlan, rima.cahdriyana@pmat.uad.ac.id \\ 2Program Studi Pendidikan Matematika, Universitas Alma Ata, rinorichardo@uaa.ac.id
}

\begin{abstract}
Abstrak
Tujuan dari penelitian ini adalah untuk memberikan studi tentang proses berpikir komputasi pembelajaran matematika. Penelitian ini menggunakan metode penelitian kepustakaan. Data yang diperoleh adalah publikasi artikel penelitian dalam jurnal ilmiah. Analisis data mencakup tiga tahap: mengatur, mensintesis, dan mengidentifikasi. Berdasarkan hasil analisis diperoleh bahwa matematika adalah pelajaran yang dapat memperkenalkan dan mengembangkan keterampilan berpikir komputasi kepada siswa..
\end{abstract}

Kata Kunci: Berpikir, Komputasi, Kritis, Matematika, Revolusi Industri.

\begin{abstract}
The purpose of this study was to provide a study of the computational thinking process of learning mathematics. This research uses the method of library research. The data obtained was the publication of research articles in a scientific journal. Data analysis includes three stages: organize, synthesize, and identify. Based on the analysis results obtained that mathematics is a lesson that can introduce and develop computational thinking skills to students.
\end{abstract}

Keywords: Thinking, Computing, Critical, Mathematics, Industrial Revolution.

\section{PENDAHULUAN}

Munculnya istilah Revolusi Industri 4.0 diabad 21 yang ditandai dengan masifnya perkembangan teknologi dan informasi. Oleh karenanya, hal ini menuntut dunia pendidikan agar mampu mendesain kurikulum dan pembelajaran sehingga peserta didik memiliki keterampilan agar dapat berdaya saing secara global. Salah satu keterampilan yang mendukung berkembangnya teknologi dan informasi salah satunya adalah kemampuan berpikir komputasi ${ }^{1}$.

${ }^{1}$ Malik, S. Peningkatan Kemampuan Berpikir Komputasi Siswa Melalui Multimedia Interaktif Berbasis Model Quantum Teaching and Learning. (Desertasi tidak dipublikasikan. Bandung : Universitas Pendidikan Indonesia, 2017)
Berpikir komputasi merupakan cara untuk menemukan pemecahan masalah dari data input dengan menggunakan suatu algoritma sebagaimana dengan mengaplikasikan melibatkan teknik yang digunakan oleh software dalam menulis program. Tetapi bukan berpikir seperti komputer, melainkan komputasi dalam hal berpikir untuk memformulasikan masalah dalam bentuk masalah komputasi serta menyusun solusi komputasi yang baik (dalam bentuk algoritma) atau menjelaskan mengapa tidak ditemukan solusi yang sesuai ${ }^{1,2}$.

${ }^{2}$ Wing, J.M. (2006). Computational Thinking, Communications of the ACM, 49 (3), 33-35. Diambil dari: https://www.microsoft.com/en-us/research/wpcontent/uploads/2012/08/Jeannette_Wing.pdf 
Berdasarkan pendapat tersebut, jelas bahwa berpikir komputasi sangat penting dimiliki oleh peserta didik diabad 21 ini. Enam tahun yang lalu, pemerintah Inggris menganggap penting kemampuan berpikir komputasi. Sehingga peserta didik pada sekolah dasar dan menengah telah mendapatkan materi pemrograman. Tujuannya bukan untuk mencetak programmer tetapi untuk mengenalkan dan mengembangkan kemampuan berpikir komputasi. Mereka percaya kemampuan ini dapat membuat siswa lebih cerdas dan membuat mereka lebih cepat memahami teknologi yang ada di sekitar mereka ${ }^{1}$.

Pertanyaannya adalah apakah berpikir komputasi hanya bisa dikenalkan pada mata pelajaran komputer atau pemrograman?, tentu saja jawabannya tidak. Berpikir Komputasi merupakan proses pemikiran yang didasari ilmu komputer tetapi dapat diterapkan dalam disiplin ilmu lain ${ }^{3}$. Oleh karena itu, dalam tulisan ini akan memaparkan lebih lanjut tetang konsep serta indikator berpikir komputasi dan bagaimana memperkenalkan proses berpikir komputasi dalam pembelajaran matematika.

\section{METODE PENELITIAN}

Metode yang digunakan dalam penelitian ini adalah penelitian kepustakaan. Metode ini terdiri dari tiga tahap: mengatur, menyinkronkan, dan mengidentifikasi ${ }^{4}$. Tahap pertama adalah mengatur literatur yang akan digunakan. Literatur ditinjau sehingga relevan dengan masalah. Pada tahap ini, penulis mencari ide, tujuan, dan kesimpulan dari beberapa literatur. Tahap kedua adalah menggabungkan hasil pengorganisasian literatur ke dalam ringkasan yang koheren, dan terkait antara literatur. Tahap

${ }^{3}$ Yadav, A., Gretter, S., Good, J., \& McLean, T. (2017). Computational Thinking in Teacher Education. Dalam Emerging Research, Practice, and Policy on Computational Thinking (h.205220). Diambil dari: https://link.springer.com/ chapter/10.1007/978-3-319-52691-1_13

${ }^{4}$ Richardo, R (2017). Peran ethnomatematika dalam penerapan pembelajaran matematika pada kurikulum 2013. LITERASI (Jurnal Ilmu Pendidikan), 7 (2), 118-125 ketiga adalah mengidentifikasi hal-hal yang dianggap sangat penting untuk dianalisis untuk mendapatkan pengetahuan baru. Melalui tahaptahap ini, artikel tersebut berisi pengetahuan, ide, atau temuan yang terkandung dalam literatur jurnal ilmiah tentang pemikiran komputasi dalam pembelajaran matematika.

\section{HASIL DAN PEMBAHASAN Berpikir Komputasi}

Dua Puluh Tiga Tahun yang lalu, istilah berpikir komputasi pertama kali diperkenalkan oleh Seymour Papert dan 10 tahun berikutnya istilah ini dipopulerkan oleh Jeanette Wing ${ }^{5}$. Berpikir Komputasi didefinisikan seperangkat proses pemikiran pemecahan masalah yang berasal dari ilmu komputer tetapi dapat diterapkan dalam domain apa pun, dalam disiplin ilmu lain melalui proses pemecahan masalah ${ }^{3}$. Definisi lain, berpikir komputasi adalah proses berpikir dalam memahami permasalahan, bernalar pada beberapa tingkat abstraksi, dan mengembangkan penyelesaian otomatis 6 .

Jelas bahwa, berpikir komputasi sangat terkait dengan pemecahan masalah. Hal ini juga disampaikan oleh Jeanette Wing bahwa berpikir komputasi merupakan berpikir yang melibatkan pemecahan masalah ${ }^{7}$. Definisi operasional berpikir komputasi sebagaimana disampaikan oleh David Barr bahwa berpikir komputasi adalah proses pemecahan masalah

${ }^{5}$ Dagienè, V., \& Sentance, S. (2016). Informatics in Schools: Improvement of Informatics Knowledge and Perception, It's computational thinking! Bebras tasks in the curriculum. Proceedings 9th International Conference on Informatics in Schools: Situation, Evolution, and Perspectives, Münster, Germany. Diambil dari : https:// link.springer.com/chapter/10.1007/978-3-319-46747-4_3

${ }^{6}$ Lee, T.Y., Mauriello, M.L., Ahn, J., \& Bederson, B.B. (2014) CTArcade: Computational thinking with games in school age children, International Journal of Child-Computer Interaction, 2 (1), 26-33. Diambil dari : https://doi.org/10.1016/j.ijcci.2014.06.003

${ }^{7}$ Román-González, M., Pérez-González, J.C., \& Jiménez-Fernández, C. (2017). Which cognitive abilities underlie computational thinking? Criterion validity of the Computational Thinking Test. Computers in Human Behavior, 72, 678-69. https://doi.org/10.1016/j. chb.2016.08.047 
termasuk merumuskan masalah, mengatur dan menganalisis data secara logis (diantaranya melalui proses abstraksi, seperti model dan simulasi), mengidentifikasi, menganalisis, dan mengimplementasikan solusi dengan langkah/ strategi yang paling efisien dan efektif ${ }^{8}$.

\section{Indikator Berpikir Komputasi}

Berpikir komputasi dapat diukur dengan memberikan soal-soal pemecahan masalah. Soal tersebut dirancang dengan langkahlangkah penyelesaian berdasarkan indikator keterampilan berpikir komputasi. Ada empat keterampilan dalam berpikir komputasi, yaitu dekomposisi permasalahan berpikir algoritma, pengenalan pola, serta abstraksi dan generalisasi ${ }^{9}$. Keterampilan-keterampilan tersebut sebagai berikut.

\section{Dekomposisi Masalah}

Keterampilan mengurai informasi/data yang besar menjadi bagian-bagian yang kecil, sehingga bagian tersebut dapat dipahami, dipecahkan, dikembangkan dan dievaluasi secara terpisah sehingga bisa lebih mudah memahami kompleksitas dari suatu masalah ${ }^{10}$.

\section{Berpikir Algoritma}

Keterampilan yang berorientasi pada kemampuan untuk memahami dan menganalisis masalah, mengembangkan urutan langkah menuju solusi yang sesuai, serta menemukan langkah-langkah pengganti untuk memastikan

${ }^{8}$ Barr, D., Harrison, J., \& Conery, L. (2011). Computational thinking: A digital age skill for everyone. Learning \& Leading with Technology 38 (6), 20-23. Diambil dari https://eric.ed.gov/?id=EJ918910

${ }^{9}$ Lee, T.Y., Mauriello, M.L., Ingraham, J., Sopan, A,. Ahn, J., \& Bederson, B.B. (2012). CTArcade: learning computational thinking while training virtual characters through game play. In CHI'12 Extended Abstracts on Human Factors in Computing Systems, Austin, Texas, USA. Diambl dari https://dl.acm.org/citation. cfm?id=2223794

${ }^{10}$ Csizmadia, A., Curzon, P., Dorling, M., Humphreys, S., Selby, C,. \& Woollard, J. (2015) Computational thinking - A guide for teachers. UK : Hodder Education - the educational division of Hachette UK

\section{Computational thinking}

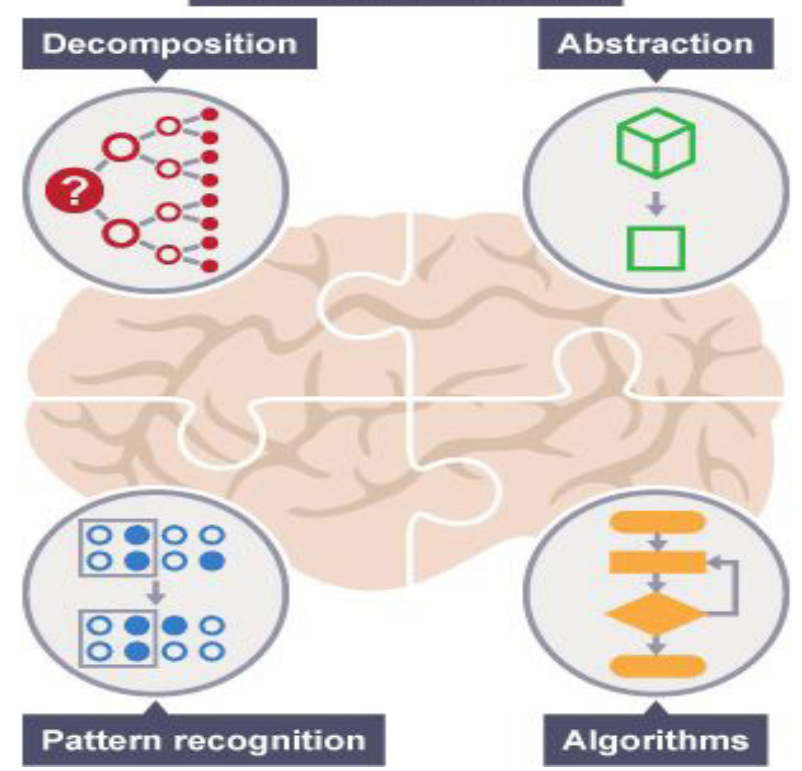

Gambar 1. Keterampilan Berpikir Komputasi. S u m ber: ht t p s : / www.pinterest.com / pin/839288080534415588

bahwa pendekatan alternatif untuk solusinya dipenuhi ${ }^{11}$.

\section{Pengenalan Pola}

Keterampilan identifikasi, mengenali dan mengembangkan pola, hubungan atau persamaan untuk memahami data maupun strategi yang digunakan untuk memahami data yang besar dan dapat memperkuat ide-ide abstraksi $^{10}$.

\section{Abstraksi dan Generalisasi}

Abstraksi terkait dengan membuat makna dari data yang telah ditemukan serta implikasinya. Sedangkan generalisasi adalah sebuah cara cepat dalam memecahkan masalah baru berdasarkan penyelesaian permasalahan sejenis sebelumnya ${ }^{10}$.

${ }^{11}$ Doleck, T., Bazelais, P., Lemay, DJ., Saxena, A., \& Basnet, R.B. (2017). Algorithmic thinking, cooperativity, creativity, critical thinking, and problem solving: exploring the relationship between computational thinking skills and academic performance. Journal of Computers in Education 4 (4), 355-369. Diambil dari https://link.springer.com/article/10.1007/s40692-0170090-9 


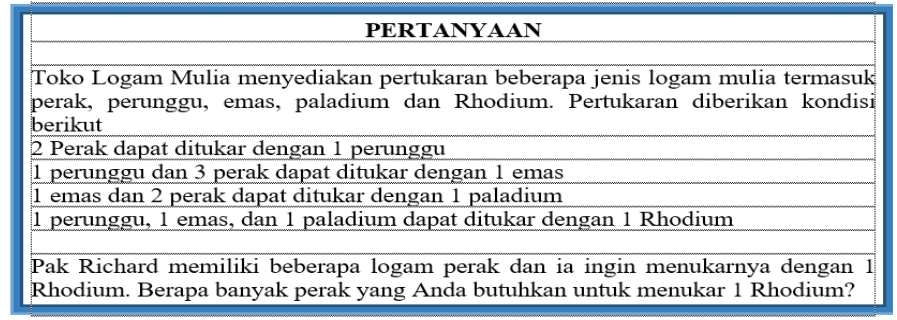

Gambar 2. Masalah Berpikir Komputasi.

\section{Berpikir Komputasi Dalam Pembelajaran Matematika}

Pemecahan masalah merupakan salah satu keterampilan yang dibutuhkan diera revolusi industri 4.0 bahkan di era selanjutnya ${ }^{12}$. Era yang menggunakan teknologi informasi dan internet dalam setiap aktivitas ${ }^{13}$. Hal ini yang menuntut peserta didik harus memiliki kemampuan beradaptasi dan mempersiapkan kompetensi terutama kemampuan berpikir bagaimana teknologi infomasi memecahkan suatu masalah. Disini peserta didik harus memiliki kemampuan algoritma berpikir yang baik sebagaimana algoritma pada program komputer yang teratur dan logis. Sedangkan berpikir logis sangat erat kaitannya dengan pemecahan masalah ${ }^{14}$. Sehingga berpikir komputasi yang proses pemikirannya berasal dari ilmu komputer merupakan kemampuan untuk memecahkan masalah yang dibutuhkan peserta didik di era revolusi industri 4.0.

Terkaitnya berpikir komputasi dengan pemecahan masalah, serta dapat diimplementasikan dalam berbagai disiplin ilmu,

${ }^{12}$ Puncreobutr, V (2016). Education 4.0: New challenge of learning. St. Theresa Journal of Humanities and Social Sciences, 2 (2). Diambil dari http://www.stic. ac.th/ojs/index.php/sjhs/article/view/Position\%20Paper3

${ }^{13}$ Wollschlaeger, M., Sauter, T., \& Jasperneite, J. (2017). The future of industrial communication: Automation networks in the era of the internet of things and industry 4.0 IEEE industrial electronics magazine. 11 (2), 17-27. Diambil dari : https://www.th-owl.de/init/ uploads/tx_initdb/IEEEMagazine.pdf

${ }^{14} E k a$, R., \& Teguh, M.B. (2018). Kemampuan Pemecahan Masalah Aljabar Siswa SMP Menggunakan Tahapan Polya Berdasarkan Kecerdasan Logis Matematis Jurnal Ilmiah Pendidikan Matematika : Mathedunesa, 7 (2). Diambil dari https://jurnalmahasiswa.unesa.ac.id/ index.php/mathedunesa/article/view/23425/21419 maka matematika merupakan bidang ilmu yang tepat sebagai sarana untuk mengembangkan kemampuan tersebut kepada peserta didik selain ilmu komputer. Hal ini dikarenakan matematika melatih peserta didik untuk berpikir secara logis, dan logis berhubungan dengan pemecahan masalah ${ }^{15,16}$. Implementasi dalam pembelajaran matematika, berpikir komputasi dapat diterapkan melalui pemberian soal-soal latihan kepada peserta didik. Berikut ini adalah contoh soal matematika bidang aljabar yang diselesaikan menggunakan indikator berpikir komputasi.

Jika Masalah dipecahkan menggunakan langkah-langkah keterampilan berpikir komputasi, solusi alternatif dijelaskan pada tabel 1.

Melalui pemberian soal-soal dengan strategi penyelesaian yang menggunakan indikator keterampilan berpikir komputasi, maka siswa akan terlatih berpikir logis, runtut serta mampu menentukan strategi yang tepat dalam menentukan solusi. Ditinjau dari keterkaitan dengan kemampuan-kemampuan berpikir dalam pembelajaran matematika dan teori pembelajarannya, berpikir komputasi sangat terkait dengan pemikiran divergen, kreativitas, pemecahan masalah, pemikiran

${ }^{15}$ Richardo, R., \& Martyanti, A. (2019). Developing ethnomathematical tasks in the context of yogyakarta to measure critical thinking ability, In Journal of Physics: Conference Series, 1188 (1). Diambil dari : https://iopscience.iop.org/ article/10.1088/1742-6596/1188/1/012063/pdf

${ }^{16}$ Cahdriyana, RA., Richardo, R., Fahmi, S., and Setyawan, F. 2019. Pseudo-thinking process in solving logic problem In Journal of Physics: Conference Series. 1188 (1). Diambil dari https://iopscience.iop.org/ article/10.1088/1742-6596/1188/1/012090/pdf 
Tabel 1. Solusi Pemecahan Masalah

\begin{tabular}{|c|c|}
\hline $\begin{array}{c}\text { Keterampilan } \\
\text { Berpikir Komputasi }\end{array}$ & Deskripsi \\
\hline Dekomposisi Masalah & $\begin{array}{l}\text { Dalam keterampilan ini, siswa diminta untuk memecah masalah menjadi beberapa bagian } \\
\text { sehingga mudah dipahami. bagian ini mencakup (1) informasi atau hal-hal yang diketahui, } \\
\text { dan (2) pertanyaan pertanyaan } \\
\text { Sehingga siswa dapat menulis } \\
\text { 1. Informasi yang diketahui dari masalah } \\
2 \text { Perak }=1 \text { Perunggu } \\
1 \text { Perunggu }+3 \text { Perak }=1 \text { Emas } \\
\quad 1 \text { Emas }+2 \text { Perak }=1 \text { Paladium } \\
1 \text { Perunggu }+1 \text { Emas }+1 \text { Paladium }=1 \text { Rhodium } \\
\text { 2. Pertanyaan tentang Berapa banyak perak yang dibutuhkan untuk menukar } 1 \text { Rhodium }\end{array}$ \\
\hline Berpikir Algoritma & $\begin{array}{l}\text { Dalam keterampilan ini, siswa diminta untuk memahami dan menganalisis masalah, } \\
\text { mengembangkan urutan langkah-langkah untuk mendapatkan solusi yang tepat. } \\
\text { Sehingga untuk mengetahui jumlah Perak yang dibutuhkan untuk } 1 \text { Rhodium } \\
\text { Langkah } 1 \\
\text { Hitung jumlah Perak untuk mendapatkan } 1 \text { perungggu } \\
\text { Langkah } 2 \\
\text { Hitung jumlah Perak untuk mendapatkan } 1 \text { Emas } \\
\text { Langkah } 3 \\
\text { Hitung jumlah Perak untuk mendapatkan } 1 \text { Paladium } \\
\text { Langkah } 4 \\
\text { Hitung jumlah Perak untuk mendapatkan } 1 \text { Rhodium }\end{array}$ \\
\hline Pengenalan Pola & $\begin{array}{l}\text { Dalam keterampilan ini, siswa diminta untuk mengenali dan mengembangkan pola, hubungan, } \\
\text { atau kesamaan untuk memahami informasi dan strategi yang digunakan. } \\
\text { Sehingga siswa dapat membuat pola sebagai sistem persamaan. Ini karena setiap persamaan } \\
\text { memiliki hubungan antara satu dan yang lainnya. } \\
1 \text { Perunggu }=2 \text { Perak ... (I) } \\
1 \text { Emas }=1 \text { Perunggu }+3 \text { Perak ..... (II) } \\
1 \text { Paladium }=1 \text { Emas }+2 \text { Perak .... (III) } \\
1 \text { Rhodium = } 1 \text { Perunggu }+1 \text { Emas }+1 \text { Paladium .... (IV) } \\
\text { Salah satu strategi yang dapat digunakan adalah metode substitusi }\end{array}$ \\
\hline $\begin{array}{l}\text { Abstraksi dan } \\
\text { Generalisasi }\end{array}$ & $\begin{array}{l}\text { Dalam keterampilan ini, siswa dapat menggunakan cara cepat dengan memilih dan } \\
\text { menghubungkan beberapa informasi yang benar. } \\
\text { Jadi, Siswa dapat menulis } \\
\text { Berdasarkan persamaan I dan II diperoleh } \\
1 \text { Emas }=5 \text { Perak ....... (V) } \\
\text { Berdasarkan persamaan III dan V diperoleh } \\
1 \text { Palladium }=5 \text { Perak }+2 \text { Perak }=7 \text { Perak ...... (VI) } \\
\text { Untuk mendapatkan } 1 \text { Rhodium, kita bisa menggunakan } \\
\text { persamaan I, V, dan VI } \\
1 \text { Rhodium }=2 \text { Perak }+5 \text { Perak }+7 \text { Perak }=14 \text { Perak. } \\
\text { Jadi, Pak Richard dapat menukar } 1 \text { Rhodium dengan } 14 \text { Perak }\end{array}$ \\
\hline
\end{tabular}

abstrak, rekursi, iterasi, metode kolaboratif, pola, sintesis dan Metakognisi ${ }^{17}$.

Ditinjau dari aspek pedagogis keterampilan komputasi dapat memperdalam

${ }^{17}$ Zapata-Ros, M. (2015) Pensamiento computacional: Una nueva alfabetización digital. Revista de Educación a Distancia, 46. Diambil dari : https:// revistas.um.es/red/article/view/240321/183001 pembelajaran konten matematika dan sains serta memberikan makna konteks (dan serangkaian masalah) di mana komputasi berpikir dapat diterapkan ${ }^{18}$. selain itu dalam matematika

${ }^{18}$ Wilensky, U,. Brady, C., \& Horn, M. (2014). Fostering computational literacy in science classrooms. Commun ACM, 57 (8), 24-28. Diambil dari : https://mcacm.acm.org/magazines/2014/8/177016-fostering- 
siswa diajarkan untuk berpikir logis, runtut, kritis, serta menggunakan strategi yang tepat dan efisien dalam menyelesaikan masalah. Berdasarkan informasi tersebut, jelas bahwa matematika dan pembelajarannya dapat diterapkan untuk mengembangkan kemampuan berpikir komputasi.

\section{KESIMPULAN}

Berdasarkan hasil dan diskusi penelitian, bahwa berpikir komputasi tidak hanya dapat dikenalkan dan dikembangkan oleh pelajaran komputer atau pemrograman, tetapi dapat diterapkan dalam berbagai disiplin ilmu. Salah satunya adalah dalam pembelajaran matematika. Terkait dengan kemampuan berpikir dalam pembelajaran matematika yang terdiri dari proses runtut dengan langkah dan prosedur yang jelas (algoritma), perhitungan (komputasi), penentuan strategi yang tepat, serta berorientasi pada pemecahan masalah. Tentunya, kesemuanya dibutuhkan dalam proses berpikir komputasi.

\section{DAFTAR PUSTAKA}

Barr, D., Harrison, J., \& Conery, L. Computational thinking: A digital age skill for everyone, (Learning \& Leading with Technology No. 6 Volume, 38, 2011)

Cahdriyana, RA., Richardo, R., Fahmi, S., and Setyawan, F. Pseudo-thinking process in solving logic problem (Journal of Physics: Conference Series, Nomor 1, Volume 1188, 2019)

Csizmadia, A., Curzon, P., Dorling, M., Humphreys, S., Selby, C,. \& Woollard, J. Computational thinking - A guide for teachers. (UK : Hodder Education - the educational division of Hachette UK, 2015)

Dagienè, V., \& Sentance, S. Informatics in Schools: Improvement of Informatics Knowledge and Perception, It's computational thinking! Bebras tasks in the curriculum. (In International Conference on Informatics in Schools:

computational-literacy-in-science-classrooms/abstract
Situation, Evolution, and Perspectives), (Proceedings 9th International Conference on Informatics), (Schools: Situation, Evolution, and Perspectives, 2016)

Doleck, T., Bazelais, P., Lemay, DJ., Saxena, A., \& Basnet, R.B. Algorithmic thinking, cooperativity, creativity, critical thinking, and problem solving: exploring the relationship between computational thinking skills and academic performance (Journal of Computers in Education, Nomor 4, Volume 4, 2017)

Eka, R., \& Teguh, M.B. Kemampuan Pemecahan Masalah Aljabar Siswa SMP Menggunakan Tahapan Polya Berdasarkan Kecerdasan Logis Matematis (Jurnal Ilmiah Pendidikan Matematika : Mathedunesa, Nomor 2, Volume 7, 2018)

Lee, T.Y., Mauriello, M.L., Ahn, J., \& Bederson, B.B. CTArcade: Computational thinking with games in school age children (International Journal of Child-Computer Interaction, Nomor 1, Volume 2, 2014)

Lee, T.Y., Mauriello, M.L., Ingraham, J., Sopan, A,. Ahn, J., \& Bederson, B.B. CTArcade: learning computational thinking while training virtual characters through game play. (In CHI'12 Extended Abstracts on Human Factors in Computing Systems), (University of Austin Texas USA, 2012).

Malik, S. Peningkatan Kemampuan Berpikir Komputasi Siswa Melalui Multimedia Interaktif Berbasis Model Quantum Teaching and Learning. (Bandung, Universitas Pendidikan Indonesia, Desertasi tidak dipublikasikan, 2017)

Puncreobutr, V. Education 4.0: New challenge of learning. (St. Theresa Journal of Humanities and Social Sciences, Volume 2, Nomor 2, 2016).

Richardo, R. Peran ethnomatematika dalam penerapan pembelajaran matematika pada kurikulum 2013. (LITERASI : Jurnal Ilmu Pendidikan, Nomor 2, Volum 7, 2017).

Richardo, R., \& Martyanti, A. Developing ethnomathematical tasks in the context of yogyakarta to measure critical thinking 
ability (Journal of Physics: Conference Series, Nomor 1, Volume 1188, 2019)

Román-González, M., Pérez-González, J.C., \& Jiménez-Fernández, C. Which cognitive abilities underlie computational thinking? Criterion validity of the Computational Thinking Test (Computers in Human Behavior, Nomor 2, Volume 7, 2017)

Wilensky, U,. Brady, C., \& Horn, M. Fostering computational literacy in science classrooms (Commun ACM, Nomor 8, Volume 57, 2014)

Wing, J.M. Computational Thinking (Communications of the ACM, Nomor 3, Volume 49, 2006)
Wollschlaeger, M., Sauter, T., \& Jasperneite, J. The future of industrial communication: Automation networks in the era of the internet of things and industry 4.0 (IEEE industrial electronics magazine, Nomor 2 , Volume 11, 2017)

Yadav, A., Gretter, S., Good, J., \& McLean, T. Computational Thinking in Teacher Education (Emerging Research, Practice, and Policy on Computational Thinking, 205-220, 2017)

Zapata-Ros, M. Pensamiento computacional: Una nueva alfabetización digital (Revista de Educación a Distancia, Volume 46, 2015) 